\title{
Three Fertility Compromises and Two Transitions
}

\author{
John C. Caldwell
}

Received: 3 September 2006/Accepted: 2 February 2007/Published online: 19 March 2008

(C) Springer Science+Business Media B.V. 2008

\begin{abstract}
Demographers and those concerned with population policy are increasingly focusing on the steep fertility declines that occurred in developed countries from the 1960 s and the consequent widespread below-replacement fertility levels. The decline has been termed the Second Demographic Transition. This paper argues that the recent demographic change can best be understood and analyzed if we broaden the concept to include the first demographic transition, and the three demographically more settled periods preceding, separating, and following the two fertility transitions. These more settled periods or "compromises" are examined to ascertain their nature and so to help predict the likely developments in the present or third compromise. It is argued that the third compromise has now extended for 20 years with little movement in fertility rates or other socioeconomic behavior which has been said to be associated with the second transition, and that this provides sufficient evidence for analysis. The approach has two key aspects. First, it is confined in Europe to countries that distinctly experienced the full five demographic periods, namely northwestern and central Europe. Second, the analysis gains strength by including non-European countries that progressed through all five stages, namely the English-speaking countries of overseas European settlement: USA, United Kingdom, Australia, and New Zealand.
\end{abstract}

Keywords Below-replacement fertility - Demographic theory ·

Demographic transition · Population policy $\cdot$ Second demographic transition

This paper seeks a unitary explanation for the fertility declines that have occurred in the economically advanced western countries since the beginning of the Industrial

J. C. Caldwell $(\bowtie)$

Demography and Sociology Program, Research School of Social Sciences, Bldg 9, Australian

National University, Canberra, ACT 0200, Australia

e-mail: Jack.Caldwell@anu.edu.au 
Revolution. It is especially concerned with the second decline that began unpredicted in the 1960s and has been widely explained in terms of ideational change.

The paper seeks explanations in the continuing transformation of the economy. The elements of that transformation were rising real per capita income, scientific and technological breakthroughs in both agriculture and industrial production, and increasing use of inanimate sources of energy. This led first to a decline in the proportion of the workforce in agriculture, and later in secondary industry with the phenomenal growth of the tertiary or service sector. This full history of economic development was not inevitable but could have stalled at any stage. The fact that it did not do so, and the movement toward a global economy, have probably now ensured that the whole world will take this path.

The declines in fertility arise from the specific nature of labor force demands. That of the first demographic transition in the late nineteenth and early twentieth century arose because men were doing different types of work from farming. This was work not done around the home and not easily learned by sons copying fathers. There came a need for universal and prolonged education to secure for the sons the better paid positions in the new society. The costs imposed directly by this education and indirectly by children being withdrawn from home production meant that large families were too expensive for most parents and so the first demographic transition took place. With increased industrial development, the demand for additional female labor grew, and from the 1960s fertility fell again, only to stabilize in the 1980s. This time the cause was not the increasing cost of children, but the incompatibility for most mothers between their work outside the home and domestic activities including childcare.

Nothing else can be regarded as a basic cause of either fertility transition. Nevertheless, the slow development of primitive means of birth control in the late nineteenth century and the explosive development of better methods in the 1960s helped dictate the exact timing and speed of the decline. Ideational changes, especially in the areas of sexuality, reproduction, and union formation, were more an effect than a cause, but probably played a limited role in accelerating fertility declines and a greater role in justifying them.

All three changes dislocated traditional family systems, with equilibrium (or "compromise") being reached not when these frictions had disappeared but when sufficient social change had occurred to make them tolerable. Below, I attempt to chart and explain these changes.

\section{The Fertility Decline}

Fertility levels are now below replacement in nearly all developed countries. The reasons for this and likely future fertility trends have become a major concern of demographers, especially those working in continental Europe where most of the lowest levels are found. Contemporary low fertility will also be the final focus of this paper. What we do know about the most recent fertility transition is that in western Europe and English-speaking countries of overseas European settlement 
fertility no longer fell steeply and usually leveled out after the mid-1980s. The decline over the previous quarter of a century has been described as the "Second Demographic Transition" (Lesthaeghe and van de Kaa 1986; van de Kaa 1987, 2003; Lesthaeghe 1995), in contrast to a first demographic transition from the late nineteenth century until the economic Depression of the 1930s. It should be noted that these terms are misleading and should be replaced by "first" and "second fertility transition" because the mortality transition, although earlier a significant determinant of fertility decline, cannot be fitted into the same time periods.

Nevertheless, the concept of a second demographic transition is a very useful analytical tool for it implies a fivefold division: (1) an initial quasi-stable fertility period, (2) the first fertility transition, (3) an inter-transition period, (4) the second fertility transition, and (5) the post-transition quasi-equilibrium. I shall employ crude birth rates to pinpoint the year when transition changes direction. Ryder (1980, pp. 17-18) has shown that in the United States the crude birth rate and total fertility rate moved together until 1947 and even thereafter changed direction in the same year. The advantage of initially employing crude birth rates is that we have them by single years for almost all western countries back to the beginning of the first fertility transition.

The analysis will concentrate on the leaders in this series of changes. This means that in Europe we will examine northern and western Europe, omitting southern and eastern Europe (Coale and Watkins 1986; Caldwell and Caldwell 2001). The south started the first transition later and had no pronounced baby boom, and consequently no marked division between the two fertility transitions. Eastern Europe, defined here as the USSR and its post-World War II satellites, is omitted, not because those countries were all late with their first transition (Hungary was among the pioneers), but because between 1945 and 1990 they had a different economic regime that guaranteed employment for young couples and promoted early marriage. During this period I use for Germany only West German statistics for the same reason. This analysis is strengthened by including three countries of English-speaking overseas European settlement (USA, Australia, New Zealand) because, in spite of their relatively high contemporary fertility levels, they have been among the leaders in the fertility changes defining the five periods. Maddison $(2001,2003)$ used the term "Western Offshoots" for these three countries plus Canada, and this term, or just "Offshoots," will be used here; Canada is omitted because of the effect of very different fertility trends among French Canadians in some periods.

The aim, then, is to examine the periods of fertility decline and those of relative stability to see if we can find explanations, and then to apply the findings to the present situation. For the periods surrounding the marked transitions we will follow Crouch (1999, p. 34 ff.) in using the term "compromise." He described the years in Europe following World War II as the "mid-century compromise," a time when western European countries had become largely industrialized, had capitalist economic systems, were sociologically liberal, and recognized citizens as having rights. Much of this can be subsumed by saying that they erected "welfare states" as real incomes rose. One value of including the Western Offshoots is that the United States was characterized by a less inclusive welfare system, while Australia and New Zealand, which led the world in welfare legislation during the first decades of 
Table 1 Fertility compromises and transitions, as defined by crude birth rates ${ }^{\mathrm{a}}$

\begin{tabular}{|c|c|c|c|c|c|}
\hline & $\begin{array}{l}\text { First } \\
\text { compromise }\end{array}$ & $\begin{array}{l}\text { First } \\
\text { transition }\end{array}$ & $\begin{array}{l}\text { Second } \\
\text { compromise }\end{array}$ & $\begin{array}{l}\text { Second } \\
\text { transition }\end{array}$ & $\begin{array}{l}\text { Third } \\
\text { compromise }\end{array}$ \\
\hline USA & Until 1861 & 1863-1933 & 1934-1958 & 1959-1984 & $1985+$ \\
\hline Australia & Until 1885 & 1886-1934 & 1935-1961 & $1962-1984$ & $1985+$ \\
\hline New Zealand & Until 1880 & 1881-1935 & 1936-1961 & 1962-1977 & $1978+$ \\
\hline England and Wales & Until 1876 & $1877-1933$ & 1934-1962 & 1963-1989 & $1990+$ \\
\hline Sweden & Until 1874 & $1875-1934$ & 1935-1964 & 1965-1994 & $1995+$ \\
\hline Denmark & Until 1884 & 1885-1933 & 1934-1965 & 1966-1983 & $1984+$ \\
\hline Netherlands & Until 1901 & 1902-1937 & $1938^{\mathrm{b}}$ & 1983 & 1984+ \\
\hline Belgium & Until 1874 & 1875-1937 & 1938-1959 & 1960-1985 & $1986+$ \\
\hline France $^{c}$ & Until 1859 & 1860-1938 & $1939^{\mathrm{b}}$ & 1993 & $1994+$ \\
\hline $\begin{array}{l}\text { Germany }^{\mathrm{d}} \text { (West } \\
\text { Germany) }\end{array}$ & Until 1876 & 1877-1932 & $1933-1963$ & 1964-1978 & $1979+$ \\
\hline Austria & Until 1876 & 1877-1937 & 1934-1963 & 1964-1987 & $1988+$ \\
\hline
\end{tabular}

Notes: Turning point only. In almost all cases identical with TFR turning point

a 1939-1949 omitted

b Continuing slow fall so no end of the Second Compromise can be identified

c The second half of France's transition

d When Germany divided, West German figures employed

Source: Mitchell 1998a, 1998b, 2003

the twentieth century, fell behind Europe in the second half of the century largely as a result of a relatively strong adherence to liberal economics.

Table 1 includes $94 \%$ of the population of northern and western Europe and $90 \%$ of the population of the Offshoots. Its dates represent the first year of change to the last before change. The countries are in groups where similar demographic behavior might be anticipated.

Table 1 shows that the first or traditional compromise ended in the 1870s or 1880 s in the majority of countries examined. Two exceptions were France and the United States where major civil upheavals upset the compromise in the late nineteenth century and the early 1860s respectively (Wrigley 1985; Hacker 2003; Caldwell 2004). In France's case the fall in birth rates stagnated in the middle years of the nineteenth century, only to begin again around 1860, and subsequently paralleling the first transition in most western European countries. It is this second part of France's first fertility transition that is shown in Table 1. In America the Civil War precipitated an increase in fertility control that would in any case have occurred within the next two decades. Everywhere, the first transition bottomed out in the economic depression of the 1930s, probably later and at a lower fertility level than would have been the case without the depression. The transition was not to be renewed for another three decades.

Three points should be emphasized. The first is the near-synchronicity of the various events across a wide spread of countries with markedly different real per capita income and human development indices. The second is that the Western 
Offshoots did not lag behind Europe and often tended to be to the fore. The third is that the second fertility transition came to a decisive halt, mostly 20 years ago, an event that has been less noted and analyzed than the low levels of fertility attained.

Table 2 uses total fertility rates (TFRs) to examine the twentieth century, showing that TFRs were already around three in the early 1920s, but in Europe half that level by the end of the century. Fertility in the Western Offshoots always tended to be somewhat higher than in Europe but that tendency was heightened by the end of the second compromise when the Western Offshoots experienced marked baby booms. Indeed, the term might never have been invented only for the Offshoots' experience. That margin of higher Offshoot fertility was maintained through the second fertility transition and into the third compromise. It was not that fertility fell more in Europe than in the Offshoots during the second fertility transition, but that it fell from a lower level. In both groups of countries $40 \%$ was a typical decline, but at its end in the mid-1980s, the Offshoots were within struggling distance of regaining

Table 2 Relative fertility levels: Twentieth century

\begin{tabular}{|c|c|c|c|c|c|c|}
\hline & Early $1920 \mathrm{~s}$ & Early to mid-1930s & 1950-1954 & 1960-1964 & 1980-1984 & 2005 \\
\hline \multicolumn{7}{|c|}{ Total fertility rates } \\
\hline USA & 2.9 & 2.0 & 3.5 & 3.3 & 1.8 & 2.0 \\
\hline Australia & 3.1 & 2.2 & 3.2 & 3.3 & 1.9 & 1.8 \\
\hline New Zealand & - & - & 3.7 & 4.0 & 2.0 & 2.0 \\
\hline Britain $^{\mathrm{a}}$ & 2.7 & 1.9 & 2.2 & 2.8 & 1.8 & 1.7 \\
\hline Sweden & 2.8 & 1.7 & 2.2 & 2.3 & 1.7 & 1.7 \\
\hline Denmark & - & - & 2.5 & 2.6 & 1.4 & 1.8 \\
\hline Netherlands & 3.6 & 2.6 & 3.1 & 3.2 & 1.5 & 1.7 \\
\hline Belgium & 2.5 & 2.0 & 2.3 & 2.7 & 1.6 & 1.6 \\
\hline France & 2.5 & 1.8 & 2.7 & 2.9 & 1.9 & 1.9 \\
\hline Germany & 2.5 & - & 2.2 & 2.5 & 1.5 & 1.3 \\
\hline Austria & - & - & 2.1 & 2.8 & 1.6 & 1.4 \\
\hline \multicolumn{7}{|c|}{ Indexed rates $(U S A=100)$} \\
\hline USA & 100 & 100 & 100 & 100 & 100 & 100 \\
\hline Australia & 107 & 110 & 91 & 100 & 106 & 85 \\
\hline New Zealand & & & 106 & 121 & 111 & 100 \\
\hline Britain $^{\mathrm{a}}$ & 93 & 95 & 63 & 85 & 100 & 85 \\
\hline Sweden & 97 & 85 & 63 & 70 & 94 & 85 \\
\hline Denmark & - & - & 71 & 79 & 78 & 70 \\
\hline Netherlands & 124 & 130 & 89 & 97 & 83 & 85 \\
\hline Belgium & 86 & 110 & 66 & 82 & 89 & 80 \\
\hline France & 86 & 90 & 77 & 88 & 105 & 95 \\
\hline Germany & - & - & 63 & 76 & 83 & 65 \\
\hline Austria & - & - & 60 & 85 & 89 & 70 \\
\hline
\end{tabular}

Note: ${ }^{a}$ United Kingdom before WW II, England and Wales after WW II

Sources: Keyfitz and Flieger 1968; Population Reference Bureau 2005; United Nations 2003 
replacement fertility levels while most of Europe was not. Britain, Scandinavia and the Netherlands occupied an intermediate position.

The paper will now concentrate on the nature of each of the five periods.

\section{Five Demographic Events}

\section{The First Compromise}

Western Europe had long been characterized by lower fertility than the rest of the world. Malthus (1798) and Hajnal (1965) identified the mechanisms and reasons, while Wrigley and Schofield (1981) provided demographic measures of England for the last three-and-a-half centuries of the compromise. The mechanism reducing family size was the delay of marriage or failure to marry at all with, outside marriage, limited sexual relations, and very limited fertility. The essential point was that some women could marry late or never, but this was facilitated by men's late marriage or celibacy. The underlying rationale was that young married persons should not live with and depend upon their parents, and hence should not marry until they could afford accommodation, furnishings, and other necessities of family life. There was strong social pressure against opting for destitution. Between 1541 and 1871 in England the proportion of women never marrying fluctuated from 27 percent in the late seventeenth century to four percent in the late eighteenth century. The mean age of female first marriage was 26.5 years in the second half of the seventeenth century, falling to 23.4 years in the first half of the nineteenth century (Wrigley and Schofield 1981, pp. 255, 260). Marriage postponement meant women losing the chance to conceive in their younger more fecund years. The Coale and Treadway (1986, p. 88) estimates for England begin only in the mid-nineteenth century, but even then female nonmarriage and postponed marriage halved potential fertility.

This system was in Crouch's sense a compromise. It had familist and societal elements. Its aim was the establishment of a sustainable household, not the reduction of fertility. The instrument was the concept of the proper time to marry. But, without any demographically significant impact of contraception (Wilson 1984), fertility remained for centuries at about two-thirds of the level found in most non-European countries not practicing fertility control. The TFR averaged 5.2 in the last six decades of the sixteenth century and 5.5 in the first seven decades of the nineteenth century (Wrigley and Schofield 1981, p. 529). The relatively low fertility in turn made its own contribution to the stability of the compromise in that it permitted life expectancies at birth around 40 years, perhaps almost twice those found then in most of Asia and Africa.

It also permitted a rise in real per capita income between 1500 and 1871 of 4.7 times in England and almost 3 times in western Europe (Maddison 2003, pp. 59-61). Indeed, the most significant aspect of the first compromise is that the demographic pattern largely remained the same as incomes rose, evidence that the minimal level of conventional necessities for establishing a household increased as incomes did. Short-term shocks were absorbed by changes in the proportions able to marry. Children were not overwhelmingly expensive, and couples who had 
excessive numbers of children could blame themselves for marrying too early or at all or for persisting too long with sexual relations. Most couples found it hard to discuss contraception, or even felt that such discussion was so immoral and irreligious that it might threaten the marriage or at least the regard the partners had for each other (Caldwell 1999). In any case contraceptive methods were few, crude, and for most couples difficult to access, and were feared to be dangerous.

\section{The First Transition}

The existing compromise was increasingly threatened by a series of changes usually termed the Industrial Revolution. Economic change accelerated. In the United Kingdom, where real per capita income had risen over 100 years by only $36 \%$ and $28 \%$ respectively during the sixteenth and seventeenth centuries, it increased by $87 \%$ in the 50 years after 1820. Farming, where children's labor was valuable, increasingly gave way to life in industrialized urban areas where their work was of less value. This problem of the decline in value of children and, indeed, their extra cost was critically increased by the growing likelihood of their being sent to school as the nineteenth century progressed and by universal schooling legislation becoming increasingly common in the last decades of the nineteenth century (Caldwell 1980). Literature began to note the problems of the large family and often ridiculed it (Kane 1995).

Nevertheless, practicing contraception was difficult and the limited demand meant that contraceptives remained primitive (see van de Walle 2005). Major social turbulence could remove the blockages to the discussion and practice of family limitation: the French Revolution started the process in France and the Civil War in America (Caldwell 2004). But elsewhere little happened until the last quarter of the nineteenth century. The tipping point in Britain seems to have been the 1877 Bradlaugh-Besant trial (Banks 1954), not because of the judicial decision, but because the rapidly expanding press reported the issues at length. An increasingly literate population found they could discuss - at least between spouses or close women friends-matters that the press found fit to print. They could even read the birth control manuals that sold widely in the years after the trial. As seen from the standpoint of the twenty-first century the transition remains remarkable. In half a century from around 1880 until the early 1930s in western Europe and its Offshoots, fertility was halved using a range of difficult methods: abstinence, abortion, some infanticide, douching with spermicides, thick rubber condoms, withdrawal, pessaries, and suppositories. It was late in the transition before Dutch caps and diaphragms became available and even then their use was largely confined to the middle classes.

An important point is that the first transition was not only the product of change but a major instrument in shaping the society that was to follow, the second compromise. The transition made the acceptance of family limitation possible, although that situation was achieved sooner by much of the populace than by governments and churches. Another point is that contraception tended to rid sexual relations of the fear of excess fertility. Marital sexual relations caused less stress, and this change was to color the twentieth century. 
The first transition finished in the depths of the Great Depression of the 1930s. This makes its probable end-point without the depression difficult to determine. Certainly, the very low fertility-below replacement level in much of western Europe - was achieved very largely by the deferment of marriage and births within marriage. It is likely that a growing proportion of the population thought of the basic family as consisting of two parents and two children. Yet it should be noted that the fertility decline was just as steep in the late 1920s as in the first half of that decade, and indeed did not slacken in the early 1930s. In contrast, and even more remarkably, the fertility decline ceased not at the end of that economically troubled decade, but early (although in its nadir), 1933-1935, in the Offshoots, Britain and Scandinavia; and in Germany as part of a political program for economic and demographic recovery. This seems to indicate that the people of these countries were aiming at least at replacement fertility.

The significance of the first fertility transition can hardly be overstated. It showed that societies, probably from then henceforth throughout history and in contrast to preceding tens of millennia, would be willing to practice birth control. By the end of the transition many governments, either national or local, were beginning to assist with family planning services. The populace had adopted the very small family without individual or national trauma. The foundation had been laid for western governments and their electorates in the second half of the twentieth century urging fertility control in developing countries and providing assistance toward that end. By the 1930s the pent-up, often unarticulated, demand for smaller families had been met, and a new kind of society constructed.

\section{The Second Compromise}

The West emerged from World War II with a strong conviction that all members of society deserved protection by the state in times of illness, unemployment, and final retirement. These attitudes were the product not only of the joint effort and joint suffering of wartime but of the experience of the preceding economic depression. Slowly the welfare states were built, most comprehensively in Scandinavia and France, least in the United States. Welfare states gave young adults a confidence of security that their parents had not felt before 1945. Yet an even greater source of confidence for young men and their families was the near-certainty of the husbands finding continuing employment, a situation that prevailed up to the oil shocks and inflationary pressures of the mid-1970s. Indeed, continued full employment gave confidence not only to individuals but also to governments because the welfare budget was boosted by taxation receipts from a maximum male work force and was not burdened by high unemployment relief. There was a prevailing belief that economists, especially as guided by Maynard Keynes's doctrines, could maintain high levels of male employment into the distant future. Crouch (1999, p. $34 \mathrm{ff}$.), as we have noted, wrote that the countries of the compromise were characterized by being predominantly industrialized; having capitalist economies even if regulated to differing degrees; being socially liberal; and accepting that citizens had basic rights that governments could not trammel and that the legal system would uphold. He 
could have added the breadwinner system with the wife staying at home looking after the children and house.

The second compromise was not demographically as stable as the first, and fertility behavior changed in a way that demographers, especially those of the 1930s, had not foreseen. Couples married at ever-earlier ages right through to the beginning of the 1970s. This is partly explained by employment security, but by no means wholly. The other factor was that sexual relations among the unmarried were still not as acceptable as relations within marriage (see Caldwell 1982). There were sound reasons for this. In a period when contraception was still not perfect and abortion illegal, hard to access and often dangerous, there was always the possibility of an unwanted pregnancy. In contrast, married couples could without too much difficulty accept an additional child, and even convince themselves that the additional birth was wanted. This was facilitated by job security, rising incomes, and the presence at home of the wife as a potential child carer. In 1970 real per capita income in western Europe was 165\% above that of 1947 (and 141\% above that of 1929) while in the Offshoots the figure was 69\% (and 118\%). Nevertheless, women who accidentally became single mothers in the 1950s found they could not easily get jobs in an essentially male labor market, had as yet little government support, and usually had less education and less employment experience than their brothers. In keeping with economic and contraceptive realities, relatives, society and employers frowned on cohabitation or single parenthood.

The solution to the problem of sexual needs was to marry ever earlier. This was especially the case in the perhaps less traditional societies of the Offshoots where by 1970 average age at female first marriage was almost as low as 20 years. In a situation of less than perfect birth control, this resulted in higher fertility rates. Table 2 shows Offshoots' TFRs climbing to 3.7-4.0, well above all western Europe except the Netherlands, which had been conspicuous in western Europe in its higher fertility throughout most of the preceding twentieth century. This phenomenon became known as the "Baby Boom." It was mainly a marriage boom with a tempo effect from the declining age at marriage and an added fertility effect from more years spent in marriage (Ryder 1980). By the second half of the 1950s long-term natural increase was at least $0.5 \%$ per annum everywhere in western Europe, rising to $0.7 \%$ in France and Denmark, while it had reached $1.5 \%$ in the Offshoots. Population growth could be said to be ominously high with most Europeans having 2-3 children and most in the Offshoots 3-4.

There was until the very end of the 1950s very little sign of marked demographic change occurring. But the second compromise, built around the husband as breadwinner, was threatened with greater strains.

The decisive strain took the form of ever more wives working outside the home in a situation where there were more young children to be cared for than had been the case for decades. The proportion of married women working had been rising consistently ever since the late 1940s. Ever-earlier marriage, particularly in Englishspeaking countries, meant that many young couples had not achieved the savings required to set up a home in the way that had been the expectation in western Europe for centuries. In these circumstances there was strong pressure on new young wives to continue in the workforce for at least some time after marriage. The 
period of two incomes was often determined by chance in that it was most likely to end, usually for good, when the wife became pregnant. The temptation to work longer after marriage or to return to work when the child was still very young became stronger. One reason was the steady growth of the consumer society with its icons, the large supermarket, the huge furniture store, the one or two cars and the foreign holiday. The temptations were too great to resist and so there was a striving for the purchasing power of two incomes.

The labor market was also becoming more attractive for women. The dirty, laborious work of the early Industrial Revolution was being carried out with a greater degree of automation; primary and secondary industrial employment together shrank to less than $50 \%$ of employment by the 1950 s, and will probably ultimately total less than $10 \%$. The new jobs were in the tertiary or service sector. The consumer industry supplied much of the employment, the new welfare systems almost as much, while teachers were needed in greater numbers especially at higher education levels, and positions at all levels of government increased. Even the factories provided more office positions. Not only was this kind of employment more attractive to both women and men, but it was also more compatible with mothers' needs to drop off and to pick up children. For many of the positions women were preferred to men, increasingly so as society became accustomed to interacting with a female workforce. While many women were going into the nondomestic workforce as their first choice, many of the remainder were driven there by the collapse of the home-centered way of life. No longer were the women next door at home during the day; no longer was it quite as respectable to confine much of one's conversation to housekeeping and childrearing; no longer were there small local stores where women could meet, as they were replaced by distant large shopping centers within easy reach of the family car (see on Australia, Caldwell and Ruzicka 1978). The more educated wives of the late 1950s began to feel unfulfilled, often without knowing quite why. Betty Friedan (1973) in The Feminine Mystique, first published in 1963 but drawing on an enquiry and an unpublished paper of 1958 , called this feeling "the problem that has no name."

The transition was accelerated by two related forces. One was the women's movement and the other the partly related moving to parity of girls' and boys' education. The women's movement was in part the justifying to working mothers of their decision to join the extra-domestic workforce, but it inevitably also queried the decision of other women to stay at home. The women's movement also inevitably put the case for gender equality in education. This was a battle easily won for two reasons. First, the egalitarian ethic found in the West since at least the Enlightenment and the French Revolution made it difficult for increasingly rich parents or governments to defend gender inequality in education, or for girls to demand the right to end their schooling. Second, educated daughters were suited to the adult jobs that were becoming increasingly available. Not only did many of the jobs require technical and verbal competence but education helped to produce the middle-class self-assured manners and diction that were expected among employees dealing directly with the public. Slowly, the older generations became accustomed to their married daughters working and even proud of their professional success. 
What troubled these two-income couples was the fear of an unplanned pregnancy. They-especially the women-found paid work plus housework together with childrearing onerous. Organized child care was expensive, especially if there were several children involved. Working mothers were also often plagued with doubts about whether it was irresponsible not to be a full-time child-carer even though academic research conveniently turned from demanding maternal care to showing that young children benefited from the experience of crêches and preschool education.

Probably the most important lesson taught by the second compromise was that, in a fixed social system, fertility can rise as incomes increase. In most of the countries examined here, family size slowly rose from the mid-1930s, disregarding the years of World War II. Nevertheless, by the late 1950s the compromise, only a quarter of a century old, was under increasing strain.

\section{Second Transition}

The solution to this problem was a technological one that was not solely targeted at the western world but which would have profound social consequences there in that it helped to mold the third compromise. This was the contraceptive (or birth control) revolution of the 1960s. This decade brought the pill (oral contraception), injectables, the IUD (in the first place the Lippes Loop), suction abortion, and greater legitimacy for sterilization and abortion. Three important points should be stressed. First, the technological breakthrough, except in the case of the pill, resulted not from the identification of western women's problems and a move to solve them, but very largely because of concern with the "population explosion" in developing countries where postwar mortality declines were producing unprecedented rates of population growth, up to three percent per annum and even higher (Caldwell and Caldwell 1986). Without this scare, Lippes would not have developed his "loop." Nor, probably, would the American Food and Drug Administration have cleared the pill so quickly for use. But it was western women who first adopted the new methods on a large scale. Second, the endless discussion of population explosion led to a revolutionary change in attitudes to reproduction. For the first time in history people began to question whether morality dictated the need to raise an ample family or indeed any children at all. For the first time, parents could not easily take the high moral ground in urging their children to reproduce soon or ever. Third, near-perfect birth control - the pill or IUD, backed up by abortion or sterilizationmet a large number of needs and radically changed society. It is possible to see a whole group of behavioral changes as having their immediate origin in potentially perfect birth control. The deeper origin of family limitation was, of course, the children's lack of economic value in industrial society. In the 15 years from the early 1960 s to the late 1970 s the total fertility rate in the countries studied here fell about $40 \%$ (United Nations 2003).

The inclusion of the Offshoots makes it possible to examine some of the explanations for the second transition offered by the Second Demographic Transition theorists. The central finding for this purpose is that the start of the 
transition in the Offshoots was in the period 1959-1962, compared with 1963 in England and 1964 or later in continental Europe (see Table 1). The innovative argument in Second Demographic Transition theory is that a whole range of social behavior, including the fertility transition, was propelled by preceding and continuing social change. Both van de Kaa and Lesthaeghe identified increasing individualism, personal fulfillment, a weakening of the power of institutions such as the church and employers, and "progressiveness" in the area of sexuality and the family. Van de Kaa (1987, p. 7 ff.) saw an origin in World War II when warfare in one's country and subsequent occupation shook up society. Lesthaeghe places a special emphasis on secularization and the waning influence of the Church.

The true origins of the second transition must lie in circumstances that affected the Offshoots at least as much as Europe. Here, problems for the Second Demographic Transition theorists begin. The Offshoots experienced no fighting on their own soil or occupation. Individuals in the Offshoots were not involved in evergreater individualistic revolt as the second half of the twentieth century rolled on. On the contrary, the battle for freedom against institutional constraints exercised by society, employers, and government reached its height in the 1960s and early 1970s, provoked by opposition to the Vietnam War and resistance in America and Australia to the draft for military service in Vietnam. These stances were made easier by continuing full employment. To some observers at that time, such as Charles Reich in The Greening of America (1970), it appeared that these new attitudes and behavior had come to stay. It was not to be so. The Vietnam War and conscription for it ended in 1975. Two years earlier the first oil shocks struck a blow at the compromise described by Crouch (1999). Inflation and unemployment led to the victory, especially in the Offshoots, of economic liberalism with its increasing enforcement of employee discipline. In due course liberal economic theories and continuing unemployment in much of Europe would also threaten the welfare state. Even the women's movement helped, for in its struggle for gender equality it had little alternative to giving respect to employment no matter how repetitive and mindless, a view not held by the rebels of the 1960s and taken by Reich (1970) to be gone for ever.

In the Offshoots, and probably too in Europe, there is little doubt that the timing and speed of the second fertility transition was dictated by the contraceptive revolution. The new contraception was so acceptable because of the increasingly difficult family situation brought about by women working outside the home. Mothers of large families felt the strain most, but the reactions of their husbands should not be underestimated: the latter were usually forced to do a greater share of household work and child care, to forgo some of the attention paid to them by wives, and to see more of the family income spent on child-minding. The evidence is that these problems would eventually have reduced family size, but certainly not as fast and probably for some time at least not as far, without the contraceptive revolution. Support for this view is provided by the dating of the American second fertility transition, which began as early as 1959 . The most likely scenario without the catalyst of the developing world's population explosion is that the contraceptive revolution would have come more slowly, more piecemeal, and with less encouragement from governments and funders. 
My greatest difference with the Second Demographic Transition theorists is their apparent view that the greater fertility control and reduction in fertility were part and parcel of a number of other changes in society and may even have been caused by them: later and less universal marriage, later childbirth, higher levels of divorce, more blended families, greater acceptance and practice of sexual activity outside marriage and of cohabitation, acceptance of same-sex relations, an understanding of voluntary childlessness and abortion, approval of even mothers of very young children working, and the collapse of censorship which once bedeviled descriptions of sexual activity. My objection is that most of these changes did not precede the contraceptive revolution, but largely followed it and can be explained by it. The exception is, of course, mothers working outside the home; even this does not explain the contraceptive innovations of the 1960s, but it does explain the speed with which they were taken up. This interpretation of the role of working mothers has parallels with McDonald (2000) as has the interpretation of the contraceptive revolution with Westoff and Ryder (1977), Murphy (1993), and Goldin and Katz (2002).

In most western countries the fertility decline was finished by the mid-1980s. Cohort analysis (Frejka and Sardon 2004; Sobotka 2004) suggests that the third compromise, at least in its early stage, will be characterized by replacement fertility in the United States, modest sub-replacement levels in the other Offshoots (but lower in Canada), somewhat lower levels still in northern and western Europe, but reproductive levels well below replacement in Germany and Austria (and in southern and eastern Europe). Most of the other social trends listed above had also drawn to a halt or slackened by the mid-1980s, thus setting the stage for the third compromise.

\section{The Third Compromise}

In the two decades after 1985 most of the measures of family and social change that moved rapidly in the previous quarter of a century became surprisingly stable. This was especially true of fertility measures, suggesting that, no matter how unsatisfactory for mothers was the balance between outside work and domestic work and how much was the cost of child care, a marginally bearable compromise had been reached. It also suggests that the preferred family size, and perhaps the attainable family size once the turn-of-the-century problems had been ameliorated, might well be, as Bongaarts $(2001,2002)$ has suggested, two children.

The patterns of change were surprisingly similar across the studied countries but must be generalized because of the belated beginning of data collection for some of the emerging behavioral patterns (Eurostat 2003, 2005; World Bank 2005). The crude marriage rate, which was depressed because of a rise in the age of marriage and the growth of numbers cohabiting or remaining single, fell from about 1970 (but almost a decade later in the United States) and did not stabilize until the 1990s. The age at first marriage for both sexes, as measured by the singulate mean age at marriage, also rose from 1970 and was still rising, but at a slower rate, by the end of the century. The crude divorce rate had been slowly rising even before 1960 and 
thereafter rose more rapidly because of both behavioral changes and legislation adjusting society to the new patterns. Even so, the divorce rates everywhere were stable or only slowly rising by the end of the 1980s. The proportion of extramarital births, largely to cohabiting couples, rose everywhere from levels around $5 \%$ before 1960 to, by $2005,25 \%$ in the Netherlands, 33\% in the USA and around $50 \%$ in Scandinavia. Childlessness typically rose from around 10\% in the 1940 birth cohort (25 years of age in 1965) to around $20 \%$ in the birth cohorts of the mid-1960s (25 years in 1990). By 1998 cohabiting levels among 16-29 year-olds in Northern Europe ranged from 30-35\% in Austria and Germany, to 35-41\% in Belgium and France, 53-56\% in Britain and the Netherlands, and 57-70\% in Scandinavia (Eurostat 2003). For some, cohabitation was a permanent alternative to marriage, but for more it was a necessary prelude to marriage: a kind of trial marriage. Increasingly cohabitation was recognized in statistics and by various legal provisions, especially those relating to property.

An important point is that this was a limited period of such change, paralleling, often somewhat belatedly, the fertility decline. In Anthony Giddens's (1990) words it was The Consequences of Modernity, but it was neither a Runaway World (Giddens's 2000 BBC Reith Lectures title) nor a voluntary Risk Society (Beck 1992). As ever, human beings were trying to limit change and minimize risk. It will be argued here that the contraceptive revolution was not one of a bundle of changes caused by "reflexive modernization" (see Beck et al. 1994), but was an intermediate cause important in determining the exact timing of most of the changes. The fact that the changes have largely run their course allows us to analyze the nature of the third compromise and speculate on the relatively slower changes henceforth likely to happen.

The contraceptive revolution, with the changed attitudes towards reproduction of the 1960s, was not in the first place fashioned for the developed world. But it came at a time when that world was developing very considerable strains and when the population debate had justified lower fertility. The main strain that did not merely follow from the new contraception but partly preceded it was the increasing temptation for mothers to enter the workforce. More income was needed so that the family could share more of the benefits of the consumer society; more jobs suitable to women were becoming available; higher levels of female education prepared women for going to work outside the home and increasingly made them feel that it was the purpose of their education; and the women's movement concurred.

The 1960s contraceptive revolution extended behavioral possibilities, but as behavior and attitudes changed so did legislation, thus reducing the risks of the new sexual behavior. Legislation or new judicial interpretation of existing laws changed the context of contraception, abortion, sterilization, divorce, cohabitation, and samesex relationships. The worrying aspect of the Giddens (1990, 1991, 1992, 1994) approach to the "post-modern" (or "post-industrial" or "information") society is that, although we are presented with a thrilling account of the ever-greater processing of information in the "reflexive project of reconstituting one's self" in an increasingly unstable world of accelerating change, the examples given are very largely focused on sexuality and on family and marital relationships or their successors. This is a focus on limited changes that were not only largely confined to 
one behavioral area, but were mostly accomplished before the publications came out.

If we accept the alternative explanation that these changes were largely brought about by the increasing technical, social, and juridical ability to control births, then why should this have such a profound impact? The answer lies in the nature of the second compromise. Children were no longer of economic value. Indeed the only way available to most women of meeting their costs was to have a lasting marriage to a male breadwinner. Only after World War II did some of the welfare states introduce financial support for single mothers, and some provision for preschool child care. Later still did most women attain the educational levels to be employable at salaries that could pay for child maintenance and care. There were good material reasons for maintaining the older (agricultural) morality urging that sexual relations should be confined to marriage and that the male breadwinners should find it difficult to break up the marriage. The premise for such behavior was no longer the age-old need to keep a family productive unit intact, but the need of women and children to form a grouping around a breadwinner and keep it intact. Indeed in the 1950s, as societies became richer and everyone wanted a share, there were more urgent reasons for the working class to maintain this stability than there had been in the poverty-stricken early Industrial Revolution. The sexual morality of the second compromise rested on the imperfections of existing birth control: contraception that was only too likely to fail, sterilization in a forbidding medical and moral context, and abortion illegal, difficult to obtain, and either expensive or dangerous. From the 1960s all this changed, especially for those couples where the female partner took the pill or used an IUD and was willing, if need be, to have an abortion, and where ultimately one of the couple was, if it was felt necessary, willing to be sterilized. Sexual activity outside marriage was also rendered less dangerous by continuing full employment and rising incomes.

The immediate effect was that cohabitation without marriage was less risky, especially for the woman, and consequently less immoral in the eyes of society and the couple's parents. Certainly, as argued by the Second Demographic Transition theorists, this was abetted by growing secularism and even the feeling that the value of the relationship could be undermined by going through an outdated, symbolic marriage ceremony and by keeping the partnership together not by bonds of affection but by legal constraints. Nevertheless, the extra legal protection offered by marriage, especially to children, and indeed its symbolic significance meant that for most young persons cohabitation was a safe stage on the way to marriage although not necessarily to the first partner.

The decline in significance of formal marriage inevitably meant that divorce was also regarded as a lesser hurdle. In the new atmosphere, society was ready for easier divorce and legislators produced laws making the whole procedure simpler. This is not the whole story. An earlier case against divorce was that the ex-wife, with less education than her husband, often with much less work experience than him, and often encumbered by children, found herself and her children mired in poverty. As women's education increased, as their work experience after marriage was more consistent, as the society grow richer, and as many welfare states offered some financial support, divorce became more rarely a material tragedy. The women's 
movement's message was mixed, but feminists certainly wanted women to be able to opt out of miserable marriages. After the enactment of easier divorce laws, divorce rates trended upwards and looked as if they would engulf most marriages, but part of the cause was a backlog of disabled marriages. In fact, once divorce rates settled down in the early to mid-1980s it appeared that only in the United States would as many as half of marriages end in divorce, and elsewhere the proportion was not likely to exceed one-third. Now that formal marriage and divorce were taken less seriously, there was a greater possibility of the first marriage being treated more like cohabitation or a trial marriage, although formal marriage was more likely to have been encumbered by children.

Now that cohabitation was more accepted, and educated and employed women wanted more work experience, more time for enriching experiences, and often successively more than one partner, age at first marriage and first birth began to rise. The rate of rise slowed down in the 1990s. For women the mean age neared 30 years in many countries and reached it in Sweden. For men it was around 31 years. The mean age of women at first birth rose to a lesser extent, because of births to young women outside formal marriage, but was still in most countries higher than women's age at first marriage. Indeed the first pregnancy may have spurred marriage. With many women deprived of births during their twenties, low completed fertility was likely to be the consequence even if larger families were originally envisaged - partly because of increased infecundity with age, and partly because life and careers had progressed to the point where another child would cause difficulties. Childlessness among working married females was increasingly accepted, especially since their companions were no longer the mother next door, but fellow career-oriented women. Cohort childlessness rose from around $10 \%$ to $20 \%$, about half the latter figure being explained by never-marrying, childless women.

Societies that took formal marriage less seriously and were not built around childbearing were more likely to accept same-sex relationships and even marriage. They were also more likely to discuss sexuality and to accept what earlier would be regarded as pornographic. Van de Kaa (1980) took these latter changes, and indeed the earlier ones too, to be signs of progressiveness and growing individualism. They seem to me to flow from the occupational and contraception revolutions in a society growing richer. In Caldwell (1982) I published a chapter arguing that in the nineteenth century increasing numbers of male breadwinners were employed in an ever-more complex urban economy with greater distinctions in employment and, at least in the middle class, a ladder with rungs for promotion. This put pressures against too large a family if, as Arsène Dumont (1890) argued, the family wanted "social capillarity." The second ladder arrived in the 1870 s and 1880s with universal schooling and children, especially sons, facing a ladder of educational achievements preceding and largely determining subsequent occupational and social achievement. This was decisive in producing the first fertility transition and establishing the small-family pattern. The third ladder came in the second half of the twentieth century when greater numbers of women sought employment and access to a career. I see no reason to change the basic analysis except to emphasize the role of two contraceptive revolutions, the first based on the increasing cost of children 
and the second on the growing inconvenience and threat to their mothers' earning power of children.

\section{Conclusion}

The nature of the third compromise is now fairly clear. The demographic and family situation is near to being stable and has been so since the mid-1980s. We are not faced by continuing social revolution. Most of the citizens of the advanced economies were not engaged in a continuing "reflexive project to find [their] identity" (Giddens 1990, p. 61). Most indeed were probably still more interested in watching (and being influenced by) television than experiencing overload from the internet. My reaction is more that of Gellner (1992, p. 63), that our task should be "the understanding of coercive and economic constraints in society," and we should be suspicious when "the cozy world of the well-heeled scholar is allowed to stand in for the harsh world outside." Our subject is the ordinary woman or man coping with the kind of society that the Industrial Revolution has brought. The commonsense individual remains, but is faced by a richer and more complex society.

The continuing Industrial Revolution has in the last half-century gone one further step. It has brought the majority of women into the workforce for much of the time. Because most women bale out of the workforce at least temporarily when children are very young and because more women than men choose to work part-time in order to cope with the disproportionate load of household and child-care tasks they perform, women's total paid work hours still average about half those of men. This is in keeping with Catherine Hakim's (2000, p. 6) finding that $20 \%$ of women want a full-time career, $20 \%$ prefer to be full-time home workers, while the remaining $60 \%$ are ambivalent and make work decisions in accordance with opportunities. But this may merely be a passing phase. The time may well come when societal attitudes give women as little choice as men about working nearly all the time.

What is often overlooked is just how stable the post-1985 compromise has proven to be over two decades. Bongaarts (2001) was skeptical about it remaining so because ideal family size data show few respondents opting for less than two children. But, especially in Europe, there may be continuing intervening problems in achieving family ideals. Chesnais (1996, p. 729) doubted if stability had been reached because fertility differences remained wide. But that has historical precedent: in the first half of the nineteenth century the Offshoots experienced much higher fertility than Northern Europe, largely because of earlier and more universal female marriage; during much of the second compromise, the Offshoots' fertility was again higher (see Table 2). Demeny (2003) implied that fertility might not rise again because Europeans accepted lower levels as shown by their very muted reactions to the situation.

This paper examines the leaders in both the first and second fertility transitions. Indeed, it represents all populations characterized by a distinct second transition. The inclusion of the Offshoots, with no experience of occupation or fighting on their own soil in World War II and no history of religious political parties, disposes of those hypothesized reasons for the fertility decline and probably to a large degree 
the hypothesis of increasing secularization being the prime mover. The cessation of the fertility decline, and of change in the bundle of behaviors noted as moving parallel to it, throws great doubt on Giddens's "reflexive project of self" being the underlying force, especially as the information revolution and economic globalization speed on and on. That leaves us with the most plausible explanation being exactly what most participants say it is, namely the conflict between mothers' work and home maintenance together with child care. The first fertility transition had a great deal to do with the rise in the monetary cost of children, the second with the additional labor costs, especially as imposed on women, of being both an income earner and a parent and homemaker.

Neither of the transitions aimed, for the majority of population, at zero fertility. The first fertility transition ended with those countries most advanced in fertility decline exhibiting completed fertility levels around two. The second transition ended with below-replacement fertility levels but most parents had at least two children. The deficit is explained by childless women, both unmarried and married. Indeed future fertility levels are likely to be decided to a large extent by the proportions childless. The important point is that both fertility transitions were of finite length: the first around 50 years and the second about 20 years. Both started with a degree of strain in the parent-child ratio. Both ceased when that strain had been sufficiently eased. Both occurred when access to new antinatal methods became available or usable. In both cases the familiarity with the new contraceptive technology, and the smaller family, resulted in turn in further familial and social change.

Human beings had changed little. Even in the years of the third compromise, most lived in families that had produced children. Most struggled to meet domestic and work obligations and did not regard themselves as needlessly affluent even when they were purchasing things the previous generation had not even thought of. It was the external world that had changed. There were plenty of available jobs for women, especially if they were educated. Social pressures had once kept women, especially mothers, out of the workforce. Now, society urged them into the workforce. We are probably not far from the situation where women will have as little choice as men about working, even Hakim's $20 \%$ who would rather be fulltime mothers and homemakers.

Finally, and perhaps most importantly, the long-term nature of the third compromise is yet to be fully discerned. Real income will rise and that may yield higher fertility. It did this during the second compromise to the surprise of most of us. The wealth of the United States is associated with, by current standards of appraisal, high fertility. Nevertheless, the chances are that in most countries, governments will be reluctant to become heavily involved in raising fertility with the accompanying necessity of imposing higher taxation; and Europe, but not the Offshoots, will sink in absolute numbers and even more in relative numbers. The nature of the Third Compromise will be addressed in a separate paper (Caldwell n.d.).

Acknowledgments This paper has benefited from assistance from Tim Adair, Julian Robert, Wendy Cosford and Milisa Haberschusz, and critical advice from Dirk van de Kaa. 


\section{References}

Banks, J. A. (1954). Prosperity and parenthood: A study of family planning among the Victorian middle classes. London, England: Kegan and Paul.

Beck, U. (1992). Risk society: Towards a new modernity. London, England: Sage.

Beck, U., Giddens, A., \& Lash, S. (1994). Reflexive modernization: Politics, tradition and aesthetics in the modern social order. Cambridge, England: Polity Press.

Bongaarts, J. (2001). Fertility and reproductive preferences in post-transitional societies. In R. A. Bulatao \& J. B. Casterline (eds.), Global fertility transition (pp. 260-281). Supplement to Population and Development Review, 27.

Bongaarts, J. (2002). The end of fertility transition in the developed world. Population and Development Review, 28(3), 419-443.

Caldwell, J. C. (1980). Mass education as the determinant of the timing of fertility decline. Population and Development Review, 6(2), 225-255.

Caldwell, J. C. (1982). An explanation of continued fertility decline in the West. In J. C. Caldwell (ed.), Theory of fertility decline (pp. 233-266). London, England: Academic Press.

Caldwell, J. C. (1999). The delayed Western fertility decline: An examination of English-speaking countries. Population and Development Review, 25(3), 479-513.

Caldwell, J. C. (2004). Social upheaval and fertility decline. Journal of Family History, 29(4), 382-406.

Caldwell, J. C. (n.d.). The Third Compromise: The new demographic equilibrium. Unpublished mimeograph.

Caldwell, J. C., \& Caldwell, P. (1986). Limiting population growth, and the Ford Foundation contribution. London, England: Pinter.

Caldwell, J. C., \& Caldwell, P. (2001). Regional paths to fertility transition. Journal of Population Research, 18(2), 91-117.

Caldwell, J. C., \& Ruzicka, L. T. (1978). The Australian fertility transition: An analysis. Population and Development Review, 4(1), 81-103.

Chesnais, J.-C. (1996). Fertility, family, and social policy in contemporary Western Europe. Population and Development Review, 22(4), 729-739.

Coale, A. J., \& Treadway, R. (1986). A summary of the changing distribution of overall fertility, marital fertility, and the proportions married in the provinces of Europe. In A. J. Coale \& S. C. Watkins (eds.), The decline of fertility in Europe (pp. 31-181). Princeton, NJ: Princeton University Press.

Coale, A. J., \& Watkins, S. C. (eds.). (1986). The decline of fertility in Europe. Princeton, NJ: Princeton University Press.

Crouch, C. (1999). Social change in Western Europe. Oxford, England: Oxford University Press.

Demeny, P. (2003). Population policy dilemmas in Europe at the dawn of the twenty-first century. Population and Development Review, 29(1), 1-28.

Dumont, A. (1890). Dépopulation et civilisation: Étude démographique. Paris, France: Lecrosnier et Babé.

Eurostat (2003). Living conditions in Europe, 1988-2003. Geneva, Switzerland: Economic Commission for Europe.

Eurostat (2005). Retrieved from: http://europaeu.int/comm/eurostat.

Frejka, T., \& Sardon, J.-P. (2004). Childbearing trends and prospects in low-fertility countries: A cohort analysis. Dordrecht, Netherlands: Kluwer.

Friedan, B. (1973 [1963]). The feminine mystique. New York: Norton.

Gellner, E. (1992). Postmodernism, reason and religion. London, England: Routledge.

Giddens, A. (1990). The consequences of modernity. Stanford, CA: Stanford University Press.

Giddens, A. (1991). Modernity and self-identity: Self and society in the late modern age. Cambridge, England: Polity Press.

Giddens, A. (1992). The transformation of intimacy: Sexuality, love and eroticism in modern societies. Cambridge, England: Polity Press.

Giddens, A. (1994). Living in a post-traditional society. In U. Beck, A. Giddens, \& S. Lash (eds.), Reflexive modernization: Politics, tradition and aesthetics in the modern social order (pp. 56-109). Cambridge, England: Polity Press.

Goldin, C., \& Katz, L. F. (2002). The power of the pill: Oral contraceptives and women's career and marriage decisions. The Journal of Political Economy, 110(4), 730-770. 
Hacker, J. D. (2003). Rethinking the "early" decline of marital fertility in the United States. Demography, 40(4), 605-620.

Hajnal, J. (1965). European marriage patterns in perspective. In D. V. Glass \& D. E. C. Eversley (eds.), Population in history: Essays in historical demography (pp. 101-146). London, England: Edward Arnold.

Hakim, C. (2000). Work-lifestyle choices in the 21st century: Preference theory. Oxford, England: Oxford University Press.

Kane, P. (1995). Victorian families in fact and fiction. London, England: Macmillan.

Keyfitz, N., \& Flieger, W. (1968). World populations: An analysis of vital data. Chicago, IL: University of Chicago Press.

Lesthaeghe, R. (1995). The second demographic transition in western countries: An interpretation. In K. O. Mason \& A.-M. Jensen (eds.), Gender and family change in industrialized countries (pp. 14-62). Oxford, England: Clarendon.

Lesthaeghe, R., \& van de Kaa, D. J. (1986). Twee demografische transities. In D. J. van de Kaa \& R. Lesthaeghe (eds.), Bevolking: Groei en krimp (pp. 9-24). Deventer, Netherlands: Van Loghum Slaterus.

Maddison, A. (2001). The world economy: A millennial perspective. Paris, France: Development Centre of the Organization for Economic Co-operation and Development.

Maddison, A. (2003). The world economy: Historical statistics. Paris, France: Development Centre of the Organization for Economic Co-operation and Development.

Malthus, T. R. (1960 [1798]). An essay on the principle of population as it affects the future of society, with remarks on the speculations of Mr. Godwin, M. Condorcet, and other writers. Reprinted in The Population Council (1960), On population: Three essays. New York: Mentor.

McDonald, P. F. (2000). Gender equity, social institutions, and the future of society. Journal of Population Research, 17(1), 1-16.

Mitchell, B. R. (1998a). International historical statistics: The Americas, 1750-1993. London, England: Macmillan Reference.

Mitchell, B. R. (1998b). International historical statistics: Africa, Asia and Oceania, 1750-1993. London, England: Macmillan Reference.

Mitchell, B. R. (2003). International historical statistics: Europe, 1750-2000. London, England: Palgrave Macmillan.

Murphy, M. (1993). The contraceptive pill and female employment as factors in fertility change in Britain 1963-80: A challenge to the conventional view. Population Studies, 47(2), 221-243.

Reich, C. A. (1970). The greening of America. New York: Random House.

Ryder, N. B. (1980). Components of temporal variations in American fertility. In R. W. Hiorns (ed.), Demographic patterns in developed societies (pp. 15-54). London, England: Taylor and Francis.

Sobotka, T. (2004). Is the lowest-low fertility in Europe explained by the postponement of childbearing? Population and Development Review, 30(2), 195-220.

United Nations (2003). World population prospects: The 2002 revision, vol. 1: Comprehensive tables. New York.

van de Kaa, D. J. (1980). Recent trends in fertility in Western Europe. In R. W. Hiorns (ed.), Demographic patterns in developed societies (pp. 55-81). London, England: Taylor and Francis.

van de Kaa, D. J. (1987). Europe's second demographic transition. Population Bulletin, 42(1), 1-57.

van de Kaa, D. J. (2003). Second demographic transition. In P. Demeny \& G. McNicoll (eds.), Encyclopedia of population, vol. 2 (pp. 872-875). New York: Thomson Gale.

Van de Walle, E. (2005). Comment prévenait-on les naissances avant la contraception moderne? Population et Sociétés, 418. Retrieved from http://www.ined.fr/fichier/t_telechargement/4432/ telechargement_fichier_fr_pop_et_soc_francais_418.pdf.

Westoff, C. F., \& Ryder, N. B. (1977). The contraceptive revolution. Princeton, NJ: Princeton University Press.

Wilson, C. (1984). Natural fertility in pre-industrial England, 1600-1799. Population Studies, 38(2), 225240.

World Bank (2005). Retrieved from: http://devdata.worldbank.org/edstats.

Wrigley, E. A. (1985). The fall of marital fertility in nineteenth-century France: Exemplar or exception? European Journal of Population, 1(1), 35-60; 1(2), 147-177.

Wrigley E. A., \& Schofield, R. S. (1981). The population history of England, 1541-1871: A reconstruction. London, England: Edward Arnold. 